\section{Disconnect between Brainstem Serotonin Neurons and Prefrontal Cortex Serotonin Receptors in Suicide}

\section{Abstract}

Serotonin neurotransmission is widely reported as reduced in suicide attempt and completion. Evidence suggests reduced serotonin innervation of the prefrontal cortex and homeostatic upregulation of postsynaptic $5-\mathrm{HT}_{1 \mathrm{~A}}$ and perhaps $5-\mathrm{HT}_{2 \mathrm{~A}}$ receptors in suicide. However, in the brainstem, we have previously found more tryptophan hydroxylase serotonin biosynthetic enzyme and more serotonin in suicide decedents suggesting serotonergic hyperfunction, but also more autoreceptor binding that could result in reduced neuronal firing. We sought evidence of a disconnect between the brainstem and prefrontal cortex examining the serotonin transporter (SERT) and $5-\mathrm{HT}_{1 \mathrm{~A}}$ receptor in the dorsal and median raphe nucleus and SERT, 5- $\mathrm{HT}_{1 \mathrm{~A}}$ and 5- $\mathrm{HT}_{2 \mathrm{~A}}$ receptor binding in prefrontal cortex and in anterior cingulate cortex postmortem.

Suicide decedents $(n=11)$ and controls $(n=18)$ died suddenly minimizing agonal effects and had a postmortem interval $\leq 24$ hour. Autoradiography was performed in right hemisphere coronal sections at a pre-genual level and in transverse sections through the brainstem.

In controls, there were correlations between DRN and MRN SERT and 5- $\mathrm{HT}_{2 \mathrm{~A}}$ receptor binding throughout prefrontal cortex, and between DRN and MRN 5- $\mathrm{HT}_{1 \mathrm{~A}}$ receptor binding and medial and ventral prefrontal cortex. In suicide decedents there were no such relationships.

The absence of correlations between brainstem source serotonergic neuron function and receptors on target neurons in prefrontal cortex in suicides suggests a disconnect that may contribute to suicide neuropathology.

Keywords: Suicide; Postmortem; Serotonin; Prefrontal cortex; Dorsal raphe nucleus; Serotonin transporter; $5-\mathrm{HT}_{1 \mathrm{~A}}$ receptor; $5-\mathrm{HT}_{2 \mathrm{~A}}$ receptor

\section{Mark D Underwood ${ }^{1,2 *}$ and Victoria Arango ${ }^{2}$
1 Department of Psychiatry, Columbia University College of Physicians and Surgeons, New York, USA \\ 2 Division of Molecular Imaging and Neuropathology, New York State Psychiatric Institute, Columbia University, New York, USA}

\section{*Corresponding author: \\ Mark D Underwood \\ झ mu20@cumc.columbia.edu}

PhD, Division of Molecular Imaging and Neuropathology, New York State Psychiatric Institute, Columbia University, 1051 Riverside Drive, Box 42, 10032, New York, USA

Tel: $646-774-7545$

Fax: 646-774-7589

Citation: Underwood MD, Arango V (2018) Disconnect between Brainstem Serotonin Neurons and Prefrontal Cortex Serotonin Receptors in Suicide. Acta Psychopathol Vol.4 No.S3:12

\section{Introduction}

Suicide attempt and completion has long been hypothesized to involve decreased serotonin (5-hydroxytryptamine, 5-HT) neurotransmission in the brain [1-4]. Less research has been done examining differences in the serotonergic neurons giving rise to the serotonergic innervation of the prefrontal cortex (PFC) in suicides, and if so, whether differences in those neurons are suggestive of altered neurotransmission or function in target regions.

Evidence for reduced serotonergic neurotransmission in the prefrontal cortex in suicide comes from several indirect lines of evidence including the cerebrospinal fluid concentration of 5-HT or its metabolite 5-HIAA [5-7], pharmacological challenge evoking 5-HT release or depletion [8-10] and direct measures from postmortem tissue such as receptor binding, receptor affinity and expression of serotonin-related genes $[8,11]$. MDD can be effectively treated clinically with serotonin selective reuptake inhibitors (SSRI), suggesting that the depressive symptomatology can be modulated by increasing intrasynaptic 5-HT levels, however, SSRI are not particularly effective at reducing suicide. 
In vivo and in vitro methods have been used to image receptor binding in brain to examine the anatomical distribution of serotonergic receptors in suicide and nonfatal suicide behavior [12-14], and how regional brain binding patterns differ from psychiatrically normal individuals. The consensus that there is a serotonin system abnormality is a lot stronger than which brain areas are involved and the direction of the difference in binding [15-18] and explanations for discrepancies include heterogeneity of the patient population, small group sizes, small effect sizes and variability in outcome measures due to demographic variables including sex and age in live cases and also postmortem interval and brain $\mathrm{pH}$ in in vitro studies.

In the present study, we used postmortem brain tissue and sought to simultaneously examine the brainstem and the prefrontal cortex in the same brain using quantitative autoradiography, from data we have previously published, in both the prefrontal cortex and in the dorsal raphe nucleus in the brainstem, where the source 5-HT synthesizing neurons reside. We combined all available cases and examined binding results using three serotonin markers in multiple prefrontal cortical brain regions assayed from cerebral hemispheres for the serotonin transporter (SERT), the $5-\mathrm{HT}_{1 \mathrm{~A}}$ receptor and the $5-\mathrm{HT}_{2 \mathrm{~A}}$ receptor and of the SERT and $5-\mathrm{HT}_{1 \mathrm{~A}}$ receptor in the dorsal raphe nucleus (DRN) and median raphe nucleus (MRN) in the brainstem.

\section{Materials and Methods}

The Division of Molecular Imaging and Neuropathology at the New York State Psychiatric Institute was the source of the brain samples. All procedures for the collection and use of brain tissue were approved by the Institutional Review Board for Human Use Considerations of the appropriate Institutions. All subjects died suddenly and had a postmortem interval (PMI, time of death to time of freezing of the brain) of 24 hours or less. The Coroner or Medical Examiner diagnosed the suicides (Table 1). Cases with an undetermined cause of death were neither included nor collected.

Quantitative in vitro receptor autoradiography in postmortem human brain was done as described [19-22]. Sequential $20 \mu \mathrm{m}$ sections were used for $\left[{ }^{3} \mathrm{H}\right]$ Cyanoimipramine, $\left[{ }^{3} \mathrm{H}\right] 8-\mathrm{OH}-D P A T$ and $\left[{ }^{3} \mathrm{H}\right]$ Ketanserin binding in the prefrontal cortex, to label serotonin transporter sites, $5-\mathrm{HT}_{1 \mathrm{~A}}$ and $5-\mathrm{HT}_{2 \mathrm{~A}}$ receptors, respectively. In the brainstem, sections were collected, and pairs of near adjacent sections used with $1 \mathrm{~mm}$ spacing throughout the rostrocaudal extent of the DRN. Preincubation in buffer was done to remove endogenous ligands and any possible exogenously administered drugs from the tissue and incubation was done with radioligand under optimal conditions determined elsewhere. Nonspecific

Table 1 Demographics.

\begin{tabular}{|c|c|c|c|c|c|c|c|c|c|c|c|c|}
\hline & \multicolumn{2}{|c|}{ Age (years) } & \multicolumn{2}{|c|}{ Sex } & \multicolumn{4}{|c|}{ Race } & \multicolumn{2}{|c|}{ PMI (hours) } & \multicolumn{2}{|c|}{ Brain pH } \\
\hline & Mean & S.E.M & Male & Female & White & Black & Asian & Hispanic & Mean & S.E.M & Mean & S.E.M \\
\hline Controls $(n=18)$ & 43 & 5 & 16 & 2 & 7 & 6 & 1 & 4 & 14.51 & 1.25 & 6.61 & 0.08 \\
\hline Suicides $(n=11)$ & 49 & 5 & 7 & 4 & 6 & 0 & 1 & 4 & 17.41 & 1.91 & 6.51 & 0.08 \\
\hline
\end{tabular}

Note: $\mathrm{PMI}=$ Postmortem interval; S.E.M. = Standard error of the mean $p>0.05$ for Age, $\mathrm{PMI}$, Brain $\mathrm{pH}$. binding was determined by incubations of adjacent sections with appropriate displacers (see below). Sections were then washed in incubation buffer at $4^{\circ} \mathrm{C}$, briefly dipped in water, dried and transferred to a desiccator until dry and ready for loading into film cassettes for exposure. Dried slides were exposed to tritium-sensitive film (Hyperfilm, Amersham, or Biomax MS film from Kodak). Sections were exposed with slide-mounted tritium standards (American Radiolabeled Chemicals, Inc.) and films were developed (Kodak D-19) for $4 \mathrm{~min}$ at $17^{\circ} \mathrm{C}$, rinsed briefly, and fixed (Kodak Rapid Fixer) for $5 \mathrm{~min}$. The tissue sections were fixed in $10 \%$ buffered formalin and stained for Nissl with thionin or cresyl violet.

Autoradiograms were quantified using a computer-based image analysis system (MCID, Imaging Research, Inc.). First, shading correction is established by acquiring a blank field at medium luminance. The MCID system calculates the mean of this field and stores a pixel-by-pixel matrix of deviation values from the mean. These deviation values are used to correct each of the image pixels to achieve proportional shade correction. Images of standards are then calibrated to femtomoles of radioligand per milligram of tissue, providing density values in units of radioligand concentration, corrected for nonlinearities. Calibrated images of total binding and nonspecific binding are aligned on separate channels and linked. By outlining the areas of interest in the image of total binding, the computer simultaneously measures densities in both channels and provides the value for specific binding. Samples of receptor binding in a given brain region are calculated as an area- weighted average to produce one specific binding density measure for that region in that individual. The coefficient of variation between individual sections from one subject is generally less than $10 \%$. At this anatomical level, samples were taken in BA8, BA9, BA46, BA45, BA47, BA11, BA12, BA24 and BA32.

\section{$\left[{ }^{3} \mathrm{H}\right]$ Cyanoimipramine (CN-IMI) binding to serotonin transporter sites}

Quantitative autoradiography of 5-HT uptake sites was performed as described elsewhere $[19,20]$. Total binding was determined with $0.4 \mathrm{nM}{ }^{3} \mathrm{H}-\mathrm{CN}-\mathrm{IMI}$ and nonspecific binding using $10 \mu \mathrm{M}$ sertraline (Figure 1). Using our assay conditions, nonspecific binding is less than $20 \%$ of total binding [19].

\section{$\left[{ }^{3} \mathrm{H}\right]$ 8-OH-DPAT binding to 5-HT1A receptors}

Quantitative autoradiography of 5- $\mathrm{HT}_{1 \mathrm{~A}}$ receptors was performed by our modifications $[19,20]$ of the protocol of Hoyer et al. $100 \mathrm{nM}$ sertraline (to block binding to the $5-\mathrm{HT}$ transporter). Nonspecific binding is determined by $1 \mu \mathrm{M} 5-\mathrm{HT}$ (Figure 1) and is approximately $10 \%$ of total binding $[19,23]$. [23]. Slides were incubated with $2 \mathrm{nM}\left[{ }^{3} \mathrm{H}\right] 8-\mathrm{OH}-D P A T$ and 


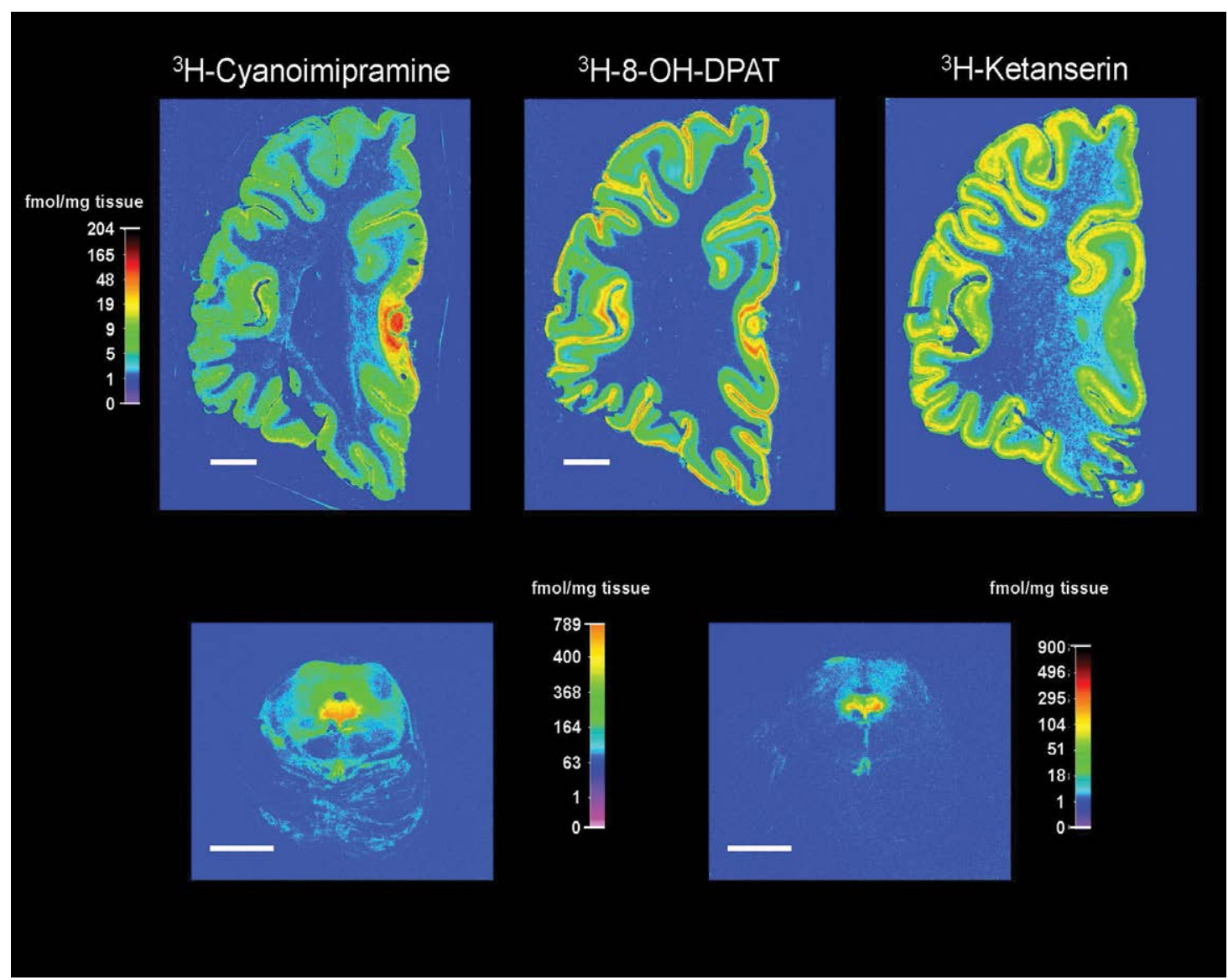

Figure 1 Consort flow diagram.

\section{$\left[{ }^{3} \mathrm{H}\right]$-Ketanserin (Ket) binding to 5-HT2A receptors}

Total binding was determined by incubation with $2 \mathrm{nM}{ }^{3} \mathrm{H}-\mathrm{Ket}, 1$ $\mu \mathrm{M}$ prazosin and $1 \mu \mathrm{M}$ tetrabenazine. Nonspecific binding was determined with $1 \mu \mathrm{M}$ mianserin (Figure 1 ) and is approximately $30-40 \%$ of total binding [23].

\section{Statistical analyses}

Statistical tests were done using SPSS (Version 24, IBM Analytics, NY) using procedures CORRELATIONS, REGRESSION and CTABLES.

\section{Results}

In controls, SERT in the DRN correlated negatively with $5-\mathrm{HT}_{2 \mathrm{~A}}$ binding in BA8 ( $r=-0.599, p=0.024, n=14)$, BA9 ( $r=-0.507, p=0.032$, $\mathrm{n}=18)$, BA46 ( $4=-0.588, p=0.031, \mathrm{n}=15), \mathrm{BA} 45(\mathrm{r}=-0.490, p=0.039$, $\mathrm{n}=18)$, BA47 ( $\mathrm{r}=-0.623, p=0.01, \mathrm{n}=16)$, BA11 $(\mathrm{r}=-0.555, p=0.017$, $\mathrm{n}=18)$, BA24 $(\mathrm{r}=-0.663, p=0.013, \mathrm{n}=13)$ and BA32 ( $\mathrm{r}=-0.514$, $p=0.035, \mathrm{n}=17)$. SERT in the MRN also had a negative correlation with $5-\mathrm{HT}_{2 \mathrm{~A}}$ binding in BA9 ( $\left.\mathrm{r}=-0.489, p=0.039, \mathrm{n}=18\right), \mathrm{BA} 46$ $(\mathrm{r}=-0.544, p=0.036, \mathrm{n}=15), \mathrm{BA} 47(\mathrm{r}=-0.527, p=0.036, \mathrm{n}=16)$ and BA11 $(r=-0.491, p=0.039, n=18)$. There were no correlations between SERT in the DRN or MRN and SERT in any region in the PFC. This suggests that less SERT in the brainstem is associated with more $5-\mathrm{HT}_{2 \mathrm{~A}}$ receptors in dorsal prefrontal cortex (Figure 2).
In controls, $5-\mathrm{HT}_{1 \mathrm{~A}}$ binding in the DRN positively correlated with $5-\mathrm{HT}_{1 \mathrm{~A}}$ binding in BA47 $(r=0.544, p=0.024, \mathrm{n}=17)$, BA11 $(r=0.493$, $p=0.038, \mathrm{n}=18), \mathrm{BA} 12(\mathrm{r}=0.517, p=0.028, \mathrm{n}=18)$ and BA32 ( $r=0.527$, $p=0.025, \mathrm{n}=18) .5-\mathrm{HT}_{1 \mathrm{~A}}$ binding in the DRN did not correlate with SERT or $5-\mathrm{HT}_{2 \mathrm{~A}}$ binding in any region in the prefrontal cortex (Figure 2). 5- $\mathrm{HT}_{1 \mathrm{~A}}$ binding in the MRN had a positive correlation with $5-\mathrm{HT}_{1 \mathrm{~A}}$ binding in BA47 ( $\left.\mathrm{r}=0.585, p=0.014, \mathrm{n}=17\right)$, but not with SERT or $5-\mathrm{HT}_{2 \mathrm{~A}}$ binding in any region.

In suicides, there was one statistically significant correlation, a positive one between $5-\mathrm{HT}_{1 \mathrm{~A}}$ binding in the MRN and SERT in BA9 (Figure 2). There were no significant correlations between SERT or $5-\mathrm{HT}_{1 \mathrm{~A}}$ binding in the DRN with any of the prefrontal cortex regions sampled $(p>0.05)$.

\section{Discussion}

Impaired serotonergic neurotransmission in the prefrontal cortex in suicide has long been hypothesized. We sought evidence suggesting that a potential contributor to the dysfunction in the prefrontal cortex was in the brainstem DRN and MRN where source serotonin-synthesizing neurons reside. We found several correlations between DRN and MRN SERT and 5- $\mathrm{HT}_{1 \mathrm{~A}}$ receptor binding and $5-\mathrm{HT}_{2 \mathrm{~A}}$ and $5-\mathrm{HT}_{1 \mathrm{~A}}$ receptor binding the PFC in normal controls, but only a single correlation in suicides. We and others have hypothesized that the greater density of postsynaptic $5-\mathrm{HT}_{1 \mathrm{~A}}$ and or $5-\mathrm{HT}_{2 \mathrm{~A}}$ receptor binding in prefrontal cortex reported in 

AND THE PREFRONTAL CORTEX (PFC) IN NORMAL CONTROLS

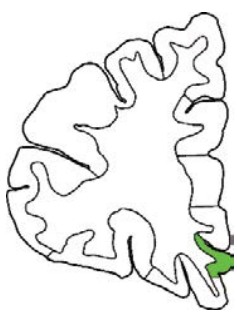

DRN SERT vs. PFC 5-HT

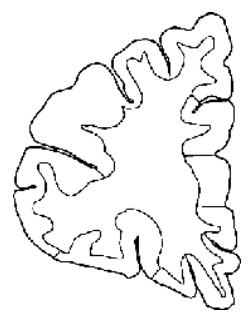

MRN SERT vs. PFC $5-\mathrm{HT}_{1 \mathrm{~A}}$

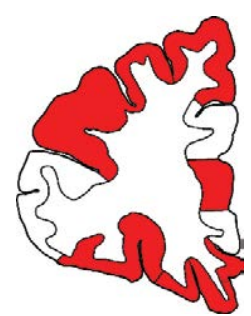

DRN SERT vs. PFC 5-HT $2 \mathrm{~A}$

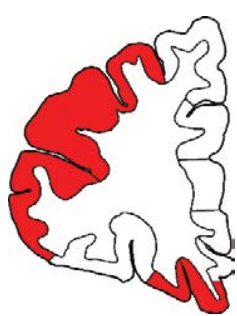

MRN SERT vs. PFC 5- $\mathrm{HT}_{2 \mathrm{~A}}$

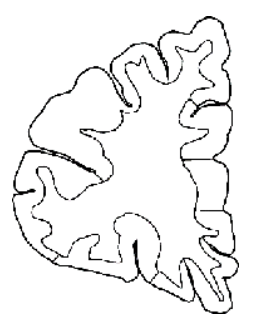

DRN SERT vs. PFC SERT

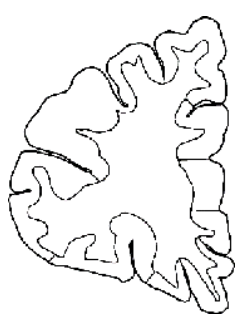

MRN SERT vs. PFC SERT

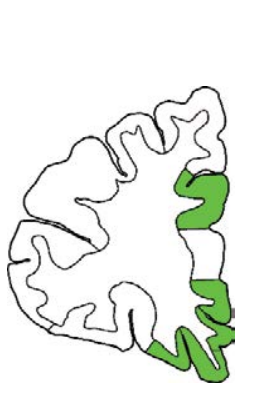

DRN 5- $\mathrm{HT}_{1 \mathrm{~A}}$ vs. PFC $5-H_{1}$

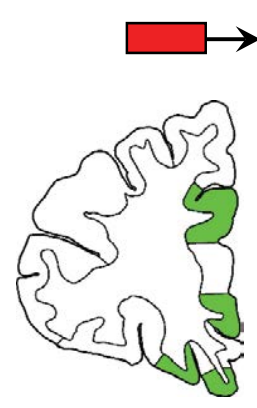

MRN 5- $\mathrm{HT}_{1 \mathrm{~A}}$ vs. PFC $5-\mathrm{HT}_{1 \mathrm{~A}}$
Negative correlation

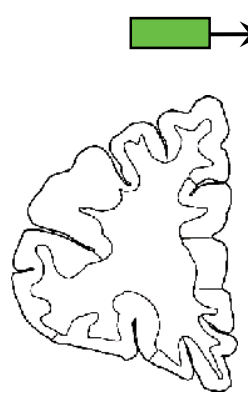

MRN 5- $\mathrm{HT}_{1 \mathrm{~A}}$ vs. PFC 5- $\mathrm{HT}_{2 \mathrm{~A}}$
Positive correlation

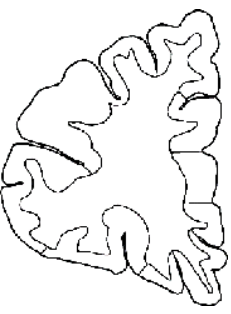

DRN 5- $\mathrm{HT}_{1 \mathrm{~A}}$ vs. PFC $5-\mathrm{HT}_{2 \mathrm{~A}}$

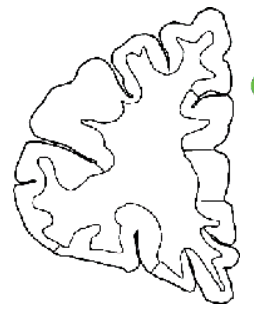

DRN 5- $\mathrm{HT}_{1 \mathrm{~A}}$ vs. PFC SERT

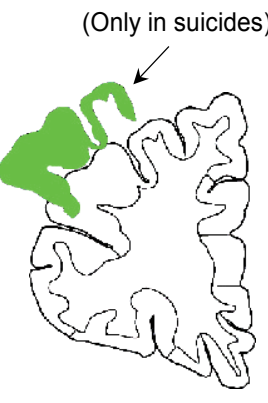

MRN 5-HT vs. PFC SERT

Figure 2 Summary of correlations between the amount of serotonin transporter and 5-HT1A receptor binding. Note that all but one of the correlations were observed in the controls. In controls, SERT in the dorsal raphe nucleus (DRN) and median raphe nucleus (MRN) was negatively correlated with 5-HT2A binding in the prefrontal cortex (PFC). 5-HT1A binding in the DRN and MRN positively correlated with medial prefrontal cortex.

suicide decedents is homeostatic upregulation in response to reduced serotonin neurotransmission. In controls, we found correlations suggesting that reduced serotonin transporters in the brainstem are associated with more $5-\mathrm{HT}_{2 \mathrm{~A}}$ receptors in the prefrontal cortex, supporting the contention that prefrontal cortex receptor levels are related to serotonin functional capacity in the DRN and MRN. However, in suicides we found no such relationships, and we believe this suggests a functional disconnect between the brainstem and prefrontal cortex may contribute to the altered serotonergic neurotransmission in suicide behavior.

\section{Serotonin receptors in the prefrontal cortex}

Some studies, though not all, in postmortem brain and live patients using PET find widespread deficits in SERT binding and increased $5-\mathrm{HT}_{1 \mathrm{~A}}$ binding in depressed individuals and medication naïve depressed subjects and in suicide attempters [17]. Discrepancies in studies of serotonin receptor binding in vivo and in vitro can arise from differences in the ligand used, antidepressant treatment, and even seasonal variation in receptor density and body mass index $[17,24]$. Likewise, pharmacologic challenge of the serotonergic system results in a blunted neuroendocrine response [9] and CSF 5-HIAA is lower in depressed subjects, in proportion to lethality of nonlethal suicide attempters [25]. Taking the postmortem and in vivo evidence in depressed suicides and suicide attempters together, the weight of evidence suggests that hypofunction of the serotonergic system is associated with the suicide phenotype and reduced serotonergic neurotransmission contributes to suicide behavior.

We observed higher $5-\mathrm{HT}_{1 \mathrm{~A}}$ receptor binding compared with controls in the ventrolateral PFC [19]. Differences in receptor binding in suicides may be related to associated psychiatric illnesses such as major depressive disorder. Parsey et al. have reported this using PET in three samples of MDD subjects and then in bipolar depression, remitted depression and in offspring of MDD [18]. In that paper it is also explained that he could match the results from other seemingly discrepant studies by changing the method for calculating PET binding [18].

Using an antagonist, we found no evidence for a significant role of the $5-\mathrm{HT}_{2 \mathrm{~A}}$ receptor in suicide [22]. The literature reports increased [22,26], decreased [27] and no change [28] in 5- $\mathrm{HT}_{2 \mathrm{~A}}$ receptors in suicide, and both increased and decreased binding in MDD in vivo [17]. One possible explanation for the discrepant reports is the use of agonist versus antagonist ligands for measuring binding. LSD is an agonist that has been used and 
detected increased binding in suicide [22,29], while ketanserin is an antagonist and has been used and detected increases or no change in suicides [24]. Furthermore, discrepancies in reports in the literature could be attributable to the confounding effects of antidepressant treatment, family history of alcohol abuse and even body mass index [17].

\section{The brainstem}

In contrast to the hyposerotonergic neurotransmission in the prefrontal cortex, in the brainstem, specifically in the DRN and MRN where 5-HT synthesizing neurons are located, there is conflicting evidence of hyperserotonergic and or hyposerotonergic function. We find greater tryptophan hydroxylase 2 protein, the rate-limiting biosynthetic enzyme for $5-\mathrm{HT}$ in brain, in the DRN of depressed suicides [30,31]. Likewise, we find an increase in the amount of TPH2 mRNA expression per neuron as well as the total number of serotonin neurons in depressed suicides $[30,32,33]$. It is not only an increase in the capacity of the DRN neurons to synthesize 5-HT, we measure more 5-HT and more of the metabolite 5-HIAA [34]. In contrast, there are fewer $5-\mathrm{HT}_{1 \mathrm{~A}}$ inhibitory autoreceptors that would functionally result in less autoinhibition of 5-HT neuron firing in caudal DRN, while in rostral DRN there are more autoreceptors which could reduce DRN firing $[20,35]$.

We hypothesize that a deficit in serotonergic transmission in the prefrontal cortex gives rise to complex and conflicting regulatory responses in the source $5-\mathrm{HT}$ synthesizing neurons in the brainstem (Figure 3). We hypothesize the lack of "normal" relationships between the amount of SERT sites and inhibitory autoreceptors in the DRN and MRN and postsynaptic 5-HT receptor subtypes in the PFC in suicides indicates a "disconnect" between the brainstem and the prefrontal cortex that we hypothesize is part of the pathobiology leading to suicide behavior. Our finding in the current study of associations in controls but not in suicides, we believe, supports this hypothesis. The upregulation in tryptophan hydroxylase and 5-HT synthesis may be offset by local 5-HT release acting on inhibitory autoreceptors to reduce serotonergic neurotransmission in the prefrontal cortex in suicide. We find more $5-\mathrm{HT}_{1 \mathrm{~A}}$ receptors in the rostral DRN in depressed suicides [35], as well as more 5-HT [34]. If so, the decrease in 5-HT receptors in the caudal DRN [35] indicates local plasticity and less autoinhibition from locally released 5-HT. Alternatively, local release of 5-HT might be sufficient to shut down $5-\mathrm{HT}$ neuron firing despite the abundant $5-\mathrm{HT}$ DRN neurons. This raises the possibility that there is less $5-\mathrm{HT}$ release in the forebrain because local $5-\mathrm{HT}$ release in the DRN acts on $5-\mathrm{HT}_{1 \mathrm{~A}}$ autoreceptors and reduces DRN neuron firing which results in less $5-\mathrm{HT}$ release in the prefrontal cortex.

\section{Disconnect between the brainstem and prefrontal cortex in suicide}

The serotonergic receptor findings of reduced SERT and increased $5-\mathrm{HT}_{1 \mathrm{~A}}$ and $5-\mathrm{HT}_{2 \mathrm{~A}}$ receptor binding in the prefrontal cortex of suicides are consistent with less serotonin or a hyposerotonergic forebrain, most likely the consequence of less serotonergic innervation from the dorsal and median raphe nuclei that give rise to the serotonin-synthesizing neurons that innervate the cerebral cortex. Reduced serotonergic function has been a long-standing hypothesis in the etiology of suicide. Data supporting this reduced serotonergic function hypothesis come from diverse studies and methodologies, including live patients and postmortem cases. The SERT is located on axons and axon terminals and are an indication of serotonergic innervation and intrasynaptic serotonin levels [36]. Less SERT binding in the prefrontal cortex in suicides therefore suggests less innervation and/or less intrasynaptic $5-\mathrm{HT} .5-\mathrm{HT}_{1 \mathrm{~A}}$ and $5-\mathrm{HT}_{2 \mathrm{~A}}$ receptors in the prefrontal cortex are located predominantly on cortical interneurons. We believe the most parsimonious explanation for more $5-\mathrm{HT}_{1 \mathrm{~A}}$ and $5-\mathrm{HT}_{2 \mathrm{~A}}$ binding in prefrontal cortex is receptor upregulation in response to less $5-\mathrm{HT}$ release. $5-\mathrm{HT}_{1 \mathrm{~A}}$

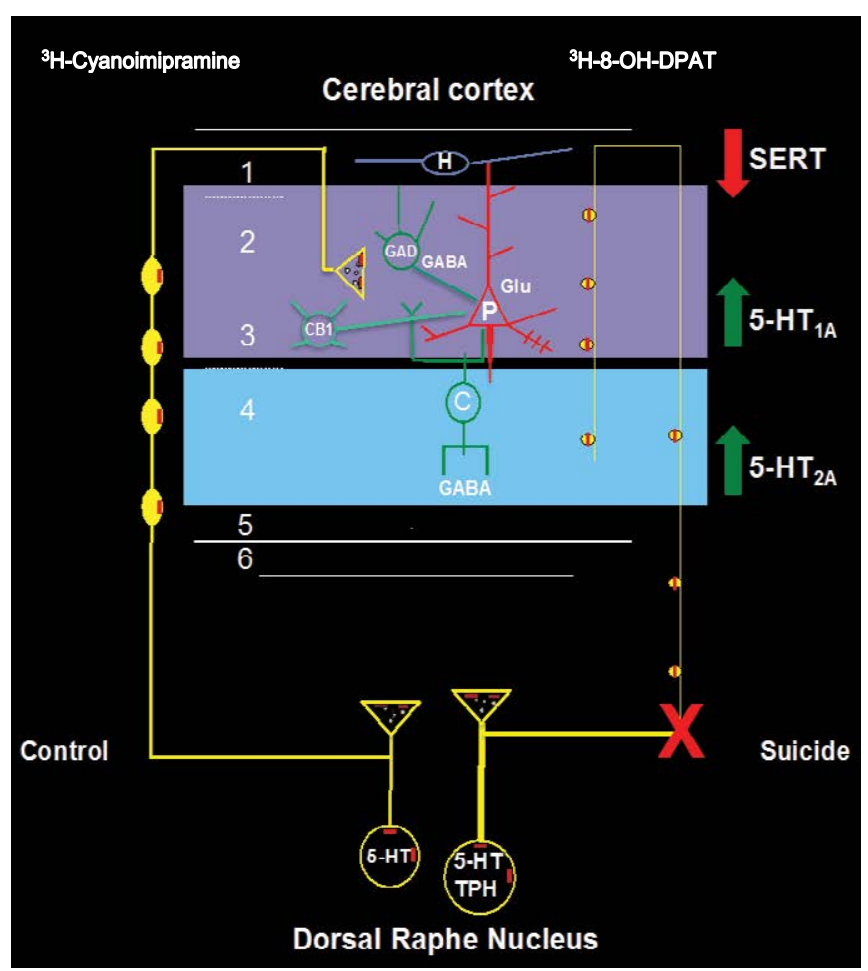

Figure 3

Schematic diagram illustrating a proposed hypothesis for plasticity and compensation in the serotonergic system in suicide. In the prefrontal cerebral cortex in suicides, there is a decrease in serotonin transporter (SERT) and more $5-\mathrm{HT}_{1 \mathrm{~A}}$ and $5-\mathrm{HT}_{2 \mathrm{~A}}$ receptor binding compared to nonpsychiatric controls. The dorsal raphe nucleus provides the serotonergic innervation to the prefrontal cortex, where 5-HT acts on 5- $\mathrm{HT}_{1 \mathrm{~A}}$ receptors predominantly on excitatory pyramidal neurons in the outer cortical layers and on $5-\mathrm{HT}_{2 \mathrm{~A}}$ receptors in deeper cortical layers with reduced serotonergic neurotransmission having an overall effect of disinhibiting neuronal activity and reducing normal levels of behavioral inhibition. In the dorsal raphe nucleus, there is not less 5-HT, as would be hypothesized by the reduced innervation of the cerebral cortex, but there is more 5-HT and more tryptophan hydroxylase 2 biosynthetic enzyme. It is hypothesized that there is an anatomical and functional disconnect between the source 5-HT neurons in the brainstem and target neurons in the prefrontal cortex. 
receptor activation results in hyperpolarization and a decrease in neuronal activity in PFC [37], on pyramidal neurons and cortical interneurons. An increase in $5-\mathrm{HT}_{1 \mathrm{~A}}$ receptors in PFC suggests an inhibition of excitatory output from cortical regions that mediate executive function and behavioral restraint. We hypothesize that reduced cortical activity may be a top down cause of a reduction in behavioral restraint and an increase in the risk for suicide behavior. Multimodal imaging studies of structure and connectivity in suicide attempters [2], such as those used in connectomic studies [38,39], support this model. We did not find any associations with the $5-\mathrm{HT}_{2 \mathrm{~A}}$ receptor in the prefrontal cortex of suicides, raising the possibility that the lack of difference is part of the neuropathology associated with suicide. Our serotonergic receptor forebrain findings are consistent with less serotonin, or with a hyposerotonergic forebrain and less serotonergic innervation from the raphe nuclei (Figure 3).

\section{Strengths and Limitations}

Correlations are not any indication of change or causation. Postmortem studies can only provide a cross-section of conditions present at a single time point, in this case at the time of death. We previously reported receptor differences associated with suicide and alcoholism and found some differences in the serotonergic system associated with diagnosis of alcohol use disorder [40]. We used as many brains as we had data available for and while for some tests the group size was notable, especially for a postmortem study, in other measures the group size was small. Findings with larger group sizes increase confidence in disease-related observations while also increasing the ability to detect differences. The larger group sizes provide more statistical power for detecting differences. Lack of reproducible findings in the postmortem literature of suicide has been attributed to effects of antemortem factors, postmortem interval, toxicology, neuropathological assessment, clinical diagnosis, brain region identification and even freezer storage time [15]. Analysis of a

\section{References}

1 Mann JJ (2013) The serotonergic system in mood disorders and suicidal behaviour. Philos Trans R Soc Lond B Biol Sci 368: 20120537.

2 van Heeringen K, Mann JJ (2014) The neurobiology of suicide. Lancet Psychiatry 1: 63-72.

3 Mann JJ, Arango V (2015) Neurobiology of suicide and attempted suicide. In: Suicide: an unnecessary death ( $2^{\text {nd }}$ Edn). Oxford OX2 6DP, United Kingdom: Global Academic Publishing, p: 286.

4 Arango V, Bach H (2014) Brain serotonin in suicides with psychological autopsy. In: A concise guide to understanding suicide (Koslow SH, Ruiz P, Nemeroff CB Edn). Cambridge: Cambridge University Press; pp: 317-324.

5 Åsberg M, Bertilsson L, Martensson B, Scalia-Tomba GP, Thorén $P$, et al. (1984) CSF monoamine metabolites in melancholia. Acta Psychiatr Scand 69: 201-219.

6 Mann JJ, Malone KM (1997) Cerebrospinal fluid amines and higherlethality suicide attempts in depressed inpatients. Biol Psychiatry 41 162-171. larger number of cases raises the possibility of including cases without regard to comorbid diagnosis which would introduce greater variability, and while this is not surprising, the gain of having a sample that is more representative of the general population, there is an inherent limitation in alternative approaches using only highly matched samples that may not be representative of either nonpsychiatric comparison controls or to the suicide groups.

Future work should involve in vivo brain imaging of the SERT and $5 \mathrm{HT}_{1 \mathrm{~A}}$ for suicide, and the $5 \mathrm{HT}_{2 \mathrm{~A}}$ receptor to validate these findings, and more importantly, to include cases with major depression and alcoholics to determine the extent that any of these differences are contributory to pathology or a consequence of the pathology or homeostatic changes suggestive of future potential therapeutic approaches to the prevention or treatment of suicide.

\section{Acknowledgements}

We acknowledge Suham A. Kassir for performing the autoradiography experiments. We are grateful to Virginia L. Johnson (autoradiography analysis) and Manuela Douglas (brain sectioning and staining) for their technical expertise. Mihran J. Bakalian performed all the statistical analyses.

\section{Funding}

This work was supported by grants from the National Institute of Mental Health and the National Institute on Alcohol Abuse and Alcoholism (MH40210, AA09004, MH62185 and AA11293) and the Diane Goldberg Foundation. Some of the brain samples and their psychiatric characterization and storage were funded by $\mathrm{NIH}$ grants MH90964 and MH64168.

\section{Conflict of Interest Disclosure}

Drs. Arango and Underwood declare no conflicts of interest.

7 Åsberg M, Träskman L, Thorén P (1976) 5-HIAA in the cerebrospinal fluid. A biochemical suicide predictor? Arch Gen Psychiatry 33: 11931197.

8 Arango V, Huang YY, Underwood MD, Mann JJ (2003) Genetics of the serotonergic system in suicidal behavior. J Psychiatr Res 37: 375-386.

9 Oquendo MA, Placidi GP, Malone KM, Campbell C, Keilp J, et al. (2003) Positron emission tomography of regional brain metabolic responses to a serotonergic challenge and lethality of suicide attempts in major depression. Arch Gen Psychiatry 60: 14-22.

10 Delgado PL, Charney DS, Price LH, Aghajanian GK, Landis H, et al. (1990) Serotonin function and the mechanism of antidepressant action. Reversal of antidepressant-induced remission by rapid depletion of plasma tryptophan. Arch Gen Psychiatry 47: 411-418.

11 Oquendo MA, Sullivan GM, Sudol K, Baca-Garcia E, Stanley BH, et al. (2014) Toward a biosignature for suicide. Am J Psychiatry 171: 1259-1277.

12 Bach H, Arango V (2012) Neuroanatomy of serotonergic abnormalities in suicide. In: The neurobiological basis of suicide (Dwivedi Y Edn). CRC Press/Taylor \& Francis; Chapter 2. 
13 Andrews PW, Bharwani A, Lee KR, Fox M, Thomson JA (2015) Is serotonin an upper or a downer? The evolution of the serotonergic system and its role in depression and the antidepressant response. Neurosci Biobehav Rev 51: 164-188.

14 Sullivan GM, Oquendo MA, Milak M, Miller JM, Burke A, et al. (2015) Positron emission tomography quantification of serotonin(1A) receptor binding in suicide attempters with major depressive disorder. JAMA Psychiatry 72: 169-178.

15 Lewis DA (2002) The human brain revisited: opportunities and challenges in postmortem studies of psychiatric disorders. Neuropsychopharmacology 26: 143-154.

16 Furczyk K, Schutová B, Michel TM, Thome J, Büttner A (2013) The neurobiology of suicide - a review of post-mortem studies. J Mol Psychiatry 1: 2.

17 Savitz JB, Drevets WC (2013) Neuroreceptor imaging in depression. Neurobiol Dis 52: 49-65.

18 Parsey RV, Ogden RT, Miller JM, Tin A, Hesselgrave N, et al. (2010) Higher serotonin $1 \mathrm{~A}$ binding in a second major depression cohort: modeling and reference region considerations. Biol Psychiatry 68: 170-178.

19 Arango V, Underwood MD, Gubbi AV, Mann JJ (1995) Localized alterations in pre- and postsynaptic serotonin binding sites in the ventrolateral prefrontal cortex of suicide victims. Brain Res 688: 121133.

20 Arango V, Underwood MD, Boldrini M, Tamir $\mathrm{H}$, Kassir SA, et al. (2001) Serotonin 1A receptors, serotonin transporter binding and serotonin transporter mRNA expression in the brainstem of depressed suicide victims. Neuropsychopharmacology 25: 892-903.

21 Underwood MD, Kassir SA, Bakalian MJ, Galfalvy H, Mann JJ, et al. (2012) Neuron density and serotonin receptor binding in prefrontal cortex in suicide. Int J Neuropsychopharmacol 15: 435-447.

22 Arango V, Ernsberger P, Marzuk PM, Chen JS, Tierney H, et al. (1990) Autoradiographic demonstration of increased serotonin 5-HT2 and beta-adrenergic receptor binding sites in the brain of suicide victims. Arch Gen Psychiatry 47: 1038-1047.

23 Hoyer D, Pazos A, Probst A, Palacios JM (1986) Serotonin receptors in the human brain. I. Characterization and autoradiographic localization of 5-HT1A recognition sites. Apparent absence of 5-HT1B recognition sites. Brain Res 376: 85-96.

24 Conwell Y, Burhan A (2003) The neuropsychiatry of suicide. In: Neuropsychiatry (Schiffer RB, Rao SM, Fogel BS $2^{\text {nd }}$ Edn). Philadelphia, PA: Lippincott Williams and Wilkins; pp: 679-723.

25 Mann JJ, Malone KM, Sweeney JA, Brown RP, Linnoila M, et al. (1996) Attempted suicide characteristics and cerebrospinal fluid amine metabolites in depressed inpatients. Neuropsychopharmacology 15: 576-586.

26 Turecki G, Briere R, Dewar K, Antonetti T, Lesage AD, et al. (1999) Prediction of level of serotonin $2 A$ receptor binding by serotonin receptor $2 \mathrm{~A}$ genetic variation in postmortem brain samples from subjects who did or did not commit suicide. Am J Psychiatry 156: 1456-1458.

27 Gross-Isseroff R, Salama D, Israeli M, Biegon A (1990) Autoradiographic analysis of $[3 \mathrm{H}]$ ketanserin binding in the human brain postmortem: effect of suicide. Brain Res 507: 208-215.

28 Stockmeier CA, Dilley GE, Shapiro LA, Overholser JC, Thompson PA, et al. (1997) Serotonin receptors in suicide victims with major depression. Neuropsychopharmacology 16: 162-173.

29 Pandey GN, Dwivedi Y, Ren X, Robert RC, Conley R, et al. (2001) Increased 5 HT2A receptors and impaired phosphoinositide siginaling in the postmortem brain of suicide victims. In: Contemporary neuropsychiatry (Miyoshi K, Shapiro CM, Gaviria M, Morita Y Edn). Tokyo: Springer-Verlag; pp: 314-321.

30 Underwood MD, Khaibulina AA, Ellis SP, Moran A, Rice PM, et al. (1999) Morphometry of the dorsal raphe nucleus serotonergic neurons in suicide victims. Biol Psychiatry 46: 473-483.

31 Boldrini M, Underwood MD, Mann JJ, Arango V (2005) More tryptophan hydroxylase in the brainstem dorsal raphe nucleus in depressed suicides. Brain Res 1041: 19-28.

32 Bach-Mizrachi H, Underwood MD, Tin A, Ellis SP, Mann JJ, et al. (2008) Elevated expression of tryptophan hydroxylase-2 mRNA at the neuronal level in the dorsal and median raphe nuclei of depressed suicides. Mol Psychiatry 13: 507-513.

33 Bach-Mizrachi H, Underwood MD, Kassir SA, Bakalian MJ, Sibille E, et al. (2006) Neuronal tryptophan hydroxylase mRNA expression in the human dorsal and median raphe nuclei: major depression and suicide. Neuropsychopharmacology 31: 814-824.

34 Bach H, Huang YY, Underwood MD, Dwork AJ, Mann JJ, et al. (2014) Elevated serotonin and 5-HIAA in the brainstem and lower serotonin turnover in the prefrontal cortex of suicides. Synapse 68: 127-130.

35 Boldrini M, Underwood MD, Mann JJ, Arango V (2008) Serotonin$1 \mathrm{~A}$ autoreceptor binding in the dorsal raphe nucleus of depressed suicides. J Psychiatr Res 42: 433-442.

36 Kovachich GB, Aronson CE, Brunswick DJ, Frazer A (1988) Quantitative autoradiography of serotonin uptake sites in rat brain using 3H-cyanoimipramine. Brain Res 454: 78-88.

37 Sprouse JS, Aghajanian GK (1986) (-)-Propranolol blocks the inhibition of serotonergic dorsal raphe cell firing by $5-\mathrm{HT} 1 \mathrm{~A}$ selective agonists. Eur J Pharmacol 128: 295-298.

38 Korgaonkar MS, Fornito A, Williams LM, Grieve SM (2014) Abnormal structural networks characterize major depressive disorder: a connectome analysis. Biol Psychiatry 76: 567-574.

39 Singh MK, Kesler SR, Hadi Hosseini SM, Kelley RG, Amatya D, et al. (2013) Anomalous gray matter structural networks in major depressive disorder. Biol Psychiatry 74: 777-785.

40 Underwood MD, Mann JJ, Arango V (2004) Serotonergic and noradrenergic neurobiology of alcoholic suicide. Alcohol Clin Exp Res 28: 57s-69s. 